\title{
Ses Yürüyüşleri ve Mekânsal Algı Çalışmalarından Kentsel Planlamaya: Kadıköy_AKUSTiK Örneği
}

\author{
Oğuz ÖNER ${ }^{1}$
}

Öz

Kentsel tasarım ve planlama çalışmaları; günümüzde kamusal alanlarda kullanıcının katıımını sağlayan, kullanıcı taleplerini dikkate alan çalışmalara giderek daha büyük önem vermektedir. Bu çalışmalar, mekanların, kullanıcıların farklı duyularına nasıl hitap ettiğini ölçümlemeyi amaçlayan psikocoğrafi araçları kullanan farklı algısal analiz çalışmalarıyla desteklenmektedir. Bu makale, İÜ Bilimsel Araştırma Projeleri (BAP) kapsamına alınan Kadıköy_AKUSTiKK isimli araştırma projesinin ve projeyi desteklemek amacıyla yürütülen diğer saha denemelerinin bir çıktısı niteliğindedir. Projenin öncelikli amacı, kentsel mekanların karakterinin belirlenmesinde "ses"in bir unsur olarak kullanılması açısından literatüre katkıda bulunmaktır. Ayrıca, bir pilot proje olarak araştırma, sesin katılımcı kentsel planlamada nasıl kullanılacağı konusunda kentsel planlamacılara ve tasarımcılara rehberlik etmeyi amaçlamaktadır.

Araştırmada işitsel peyzaj teorilerini temel alan psikocoğrafik analiz yöntemleri kullanılmıştır. Burada kentsel planlama çalışmalarında kullanıcının duyusal tepki, davranış ve isteklerinin araştırııması, bu sayede kentsel alanların anlamsal analizi ve tamamen faydacı bir kentsel tasarıma yeni alternatifler üretebilecek, alanı "akort etme" pratiği önerilmektedir. Araştırma projesi deneyimini aktaran bu makale, İstanbul'un önemli kentsel mekanları arasındaki Kadıköy Meydanı'nın çevresel akustiğini geliştirmeye yönelik mekâna özgü tasarlanan ve uygulanan mekânsal okuma yöntemlerinden ses yürüyüşleri ve zihin haritalama atölyeleri gibi katılımcı psikocoğrafi çalışmalara odaklanmaktadır.

Anahtar Kelimeler: İşitsel Peyzaj, Ses Yürüyüşü, Şehir Planlama, Kadıköy Meydanı, İşitsel Peyzaj Yönetimi

\section{From Soundwalks and Spatial Perception Studies To Urban Planning: The Case of Kadıköy_AKUSTiK}

\begin{abstract}
\footnotetext{
${ }^{1}$ İstanbul Teknik Üniversitesi, Fen Bilimleri Enstitüsü, Şehir ve Bölge Planlama Bölümü

* Illgili yazar/Corresponding author: oneroguz010@gmail.com

Gönderim Tarihi / Received Date: 03.04.2020

Kabul Tarihi / Accepted Date: 22.10.2020
}

Urban design and planning studies are increasingly giving importance to the studies that ensure the participation of the user in public spaces and take into account user demands. These studies are supported by different perceptual analysis studies, which use psychogeographic tools to measure how spaces appeal to different senses of users. This article is an output of the research project named Kadıköy_AKUSTIK and other field studies carried out to support the project, which is included in the scope of ITU Scientific Research Projects (BAP). The primary purpose of the project is to contribute to the literature in terms of using "sound" as an element in determining the 
character of urban spaces. In addition, as a pilot project, this research aims to guide urban planners and designers on how to use sound in participatory urban planning.

In the research, psychogeographic analysis methods based on soundscape theories were used. Here, it is suggested to investigate the sensory response, behaviour and desires of the user in urban planning studies. In this way, semantic analysis of urban areas and the practice of "tuning" the area, which can produce new alternatives to a purely utilitarian urban design, are proposed. This article, which conveys the experience of the research project, focuses on participatory psychogeographic studies such as spoken reading methods and mind mapping workshops, which are spatial reading methods designed and applied to develop the environmental acoustics of Kadıköy Square, one of the important urban areas of Istanbul.

Keywords: Soundscape, Soundwalk, Urban Planning, Kadıköy Square, Soundscape Management

\section{GiRiş}

Bu makale, öncelikle mekânın çeşitli kullanıcı profilleri tarafından işitsel anlamda okunabilmesi için kent plancıları ve kentsel tasarımcılarının çalışmalarına entegre etmesini önerdiğim işitsel peyzaj yaklaşımına ve bu kapsamda ses yürüyüşü yöntemine odaklanmaktadır. Uzun vadede mekânların rahat ve kullanıcı isteklerine yanıt verebilen şekilde kullanımının sağlanması için görsel verilere yönelik analiz, tasarım ve inşa çalışmalarının ötesine bakmak gerekir. Bu bağlamda çalışmada, işitsel verileri ve "ses"in algısal verilerini planlama aşamasında devreye sokmanın gerekliliğinden bahsedilmektedir. Bu sayede, Davies'in (2007) değindiği gibi akustik kentsel çevre ile ilgili insanların deneyimlerini ve algılarını anlamaya yönelik, planlama disiplinine katkı sağlayacak metodolojik yönteme yön verilmektedir.

Bu kapsamda zihin haritaları ve kullanıcının gözleri kapalı olarak gerçekleştirilen ses yürüyüşü gibi katılımcı atölye çalışmalarını kapsayan, Türkiye'nin en büyük kenti İstanbul'un merkezi kentsel mekânlarından ve dönüşüm alanlarından Kadıköy Meydanı'na yönelik algılama-mekânı okuma yöntemleriyle "Kadıköy AKUSTíK" adlı işitsel peyzaj araştırma çalışması ve bu araştırmayı destekleyecek Ekinlik Adası Ses Yürüyüşü Pilot Projesi ile TÜBITAK 4004 Projesi kapsamındaki Kentin Sesleri alt çalışmaları yürütülmüştür. Literatürde ses yürüyüşlerinin tasarım ve planlama disiplinlerinde kullanılmasına ilişkin sınırlı sayıda araştırma mevcuttur. ITÜ Bilimsel Araştırma Projeleri (BAP) kapsamında, Tasarım Atölyesi Kadıköy (TAK) ve İstanbul Kültür Sanat Vakfı (IKKSV) Tasarım Bienali iş birliğiyle yürütülen Kadıköy_AKUSTíK çalışmasının, sesin mekân karakterinin belirlenmesinde bir öge olarak değerlendirilmesi ve mekânın akustik karakterinin ortaya konulması anlamında literatüre katkı sağlanması beklenmektedir. Genel itibariyle planlama dünyasının işitsel peyzaj yaklaşımından uzak olduğu düşünülerek, "ses yürüyüşü" yönteminin planlama dünyası ile tanıştırılması ve planlama literatürüne teorik katkıda bulunulması hedeflenmektedir.

Ses ve akustik ekoloji araştırmacısı Murray Schafer'in işitsel peyzaj teorileri, Westerkamp ve Schulte-Fortkamp gibi 21. yüzyıl kent araştırmacılarının ses yürüyüşü ve mekân algısı deneyimlerinin çıktıları ve güncel psikocoğrafya çalışmalarının yöntem ve sonuçları makalede yer alan deney ve çalışmaların dayanağı niteliğinde olmuştur. $\mathrm{Bu}$ sayede kentin semantik incelenmesi ve kentsel mekânın analizi, "mekânın akordunun yapılarak" yeniden düzene sokulması pratiği, duyma biçimimize yeniden 
enerji vererek, mimarinin, kent planlamanın ve kent yönetiminin sadece fiziki / görsel ve fonksiyonel unsurlara indirgenmesi durumuna yeni ve taze seçenekler sunabilmektedir.

\section{SES, KENT VE ALGI}

Ses; günümüzde kente dair dinamikleri, algıları ve sosyopolitik özellikleri anlamak üzere kullanılabilmektedir. Özellikle ses, dinlenen ve üzerinde araştırma yapılan bir kaynak olduğunda; görünür olmayanı gösterebilmekte, erişilemeyeni erişir hale getirebilmektedir. Bir kişi mekânı dinlediğinde farklı alanlar, insanlar, makineler ve hatta göremediği nesneler arasında belli etkileşimleri duyumsar (Çağlar, 2013). Walter Jackson Ong (2012) "Ses beni dünyanın ortasına yerleştiriverir" ifadesinde de insanın dünyayla ve nesnelerle bağlantısının ve konumunun ses ve duyma üzerinden nasıl şekillendiğine değinmektedir.

Görmek, lineer bir olaydır. Gözle görülen ile gören arasında lineer bir çizgi oluşur. Duymak ise hacim içeren, dairesel/etrafı saran, üç boyutlu bir etkileşimle gerçekleşir. Aynı anda farklı katmanlarda ve farklı yönlerde bulunan ses kaynakları duyumsanır. Mekân duyulup dinlendiğinde bütünsel anlamda ruhunu, karakterini, enerjisini salıverir. Mekân içinde dinleyerek atılan her adım, mekân ile iletişime girmek üzere kullanıcıya daha fazla veri sunar. Bu veriler yukarıda bahsedildiği gibi kulakları çemberleyerek saran (surround), üç boyutlu bir duyumsama sayesinde bireyin algı alanında da farklı ve çok sayıda katmanlara ulaşır ve hafızamızın farklı odalarında kendilerine yer bulurlar. Dolayısıyla belli bir mekânda işitsel anlamda bireye sunulan peyzajdaki ses katmanları o kişinin ruh halini, hissini belirleyebildiği gibi, uzun vadede tekrarlanan / benzer karakter ve yapıda sunulan işitsel peyzaj, bireyin mekâna ilişkin tutumunu, mekânla kurduğu bağın niteliğini belirler. Mekânı kullanan kişinin de elbette mekânın işitsel peyzajını etkilemesi, peyzaja kendisini kabul ettirmesi, armoni (uyum) içinde olması ya da kendisi için farklı bir işitsel alan / katman yaratması mümkündür. Böylelikle kullanıcı da mekân ile konuşarak, ilgili ses örtüsüne müdahil olarak mekânın karakterini, enerjisini etkileyebilir. Dinleme durumu, çift yönlü, birbirini tamamlayan bir diyalog ve bağ oluşturur. Mekân ile işitsel iletişim bu yönde gelişir. Tıpkı iki birey arasındaki iletişim gibi.

Literatürde ses ve mekân iletişiminin ana eksenine oturan İşitsel Peyzaj- diğer adıyla ses peyzajı (soundscape)- kavramı, İngilizcedeki yine görme duyusuna ilişkili peyzaj (landscape) kavramından ortaya çıkmıştır. Tanımsal anlamda, akustik bir çevrenin birey, grup ve/veya toplum tarafından algılanma, anlaşılma biçimi olarak özetlenebilir (Yang \& Kang, 2005).

İşitsel peyzaj, görülen değil duyulan olaylardan oluşur. Resim nasıl görsel etkileşimlerin toplamı ise işitsel peyzaj işitilen olayların toplamıdır. John Cage'in "4'33" adlı 1952 yılında gerçekleştirdiği performansında insanların sessizliğe (ve dolaylı olarak gürültüye) dair algısını ters düz eden bir yaklaşım çağdaş sanat literatürüne kazandırılmış, işitsel peyzaj kavramı ilk kez irdelenmiştir (URL-1).

Bir ses ortamını duyan birey ile ses ortamı arasındaki iletişimde ekolojik bir dengeden söz edilebilmektedir. Bununla ilgili olarak 'Iş̧itsel Peyzaj Ekolojisi' (Soundscape Ecology) kavramı ortaya çıkmıştır. Literatüre "akustik ekoloji" olarak geçen ifade, işitsel peyzaj ekolojisi ile aynı anlamda kullanılmaktadır. Bu kavram "bir işitsel peyzajın, içinde yaşayanların fiziksel tepki ve davranışsal özellikleri üzerinde yarattığı etkileri araştıran alan" şeklinde ifade edilebilir (Truax, 1978). Aynı kavramı Schafer (1977) "insanlar ve sessel çevreler arasındaki sistematik ilişkileri inceleyen alan" olarak tanımlamaktadır. 
Kentsel planlama ve tasarım çerçevesinde ise işitsel peyzaj, bir mekâna ilişkin akustik özelliklerin tümünün algılattığı karakter olarak tanımlanabilir. Gürültü kavramından farklı olarak işitsel peyzaj; sesi negatif bir unsur olarak ele almaz, bunun yerine mekânın karakterinin bir parçası, fiziksel çevrenin bir elemanı olarak değerlendirir. Bu fiziksel elemanın mekânın kullanıcıları tarafından nasıl algılandığı bilgisi işitsel peyzaj planlaması açısından son derece önemlidir. Çünkü işitsel peyzaj, ancak akustik çevre ve insan algısı arasındaki ilişkisiyle var olabilmektedir.

\subsection{Ses kontrolünden işitsel peyzaj planlamasına}

Gürültü veya ses kontrolü; herhangi bir ses kaynağından yayılan gürültü niteliğine sahip sesleri kabul edilebilir seviyeye indirmek, akustik özelliği değiştirmek, etki süresini azaltmak, daha az rahatsız eden bir başka ses ile maskelemek gibi yöntemlerle sesin zararlı etkilerini tam olarak giderme veya makul bir seviyeye indirme işlemidir (Anonim, 1999). Ses kontrolü; işitsel peyzaj ile ilgili birikim ve araştırma verisi olmayan coğrafya ve durumlarda en yaygın kullanılan yaklaşımdır. Bu yaklaşım, mekân kullanıcısının işitsel algı verilerini ve bu çerçevede rahatsı edici / nötr / keyifli / korunmaya değer bulduğu ses kaynaklarıyla özel olarak ilgilenmemektedir. Genel kural ve esaslarla çevreyi rahatsız edebilecek yüksek desibeldeki ses kaynaklarına yönelik "tıraşlama" ve/ya yok etme yöntemi kullanılan bu yöntemdeki sakınca, kullanıcının intiyacı çerçevesinde ses kaynağının niteliği, mekân kimliğine katkısı ve algısal değeri belirlenmeden mekâna özgü seslerin basitçe ortadan kaldırılmasıdır.

İşitsel peyzajın planlamasında ise ses; gürültü / ses kontrolü yaklaşımından farklı olarak, mekânı tanımlayan bir eleman olarak değerlendirilir. Schafer'a (1977) göre bir mekândaki sesleri incelemeye almadan "tıraşlamak", maskelemek ya da yok etmek olumsuz bir yaklaşımdır ve bunun yerine öncelikle mekânın işitsel peyzajının tanımlaması ile hangi seslerin korunması, güçlendirilmesi ya da ortadan kaldırılması daha iyi anlaşılacaktır.

Günümüzde uluslararası planlama çalışmalarındaki ses kontrolü yaklaşımının, çoğunlukla üstten alta yapılanma yaklaşımı sergileyişinden bahsedilebilir. Akustik mimari ve akustik bilimler ışığında çalışan araştırmacı-uzmanlar, çoğu zaman laboratuvar ölçümleri, sahada desibel $(\mathrm{dB})$ dengeleri gözlemleri, gürültü azaltma eğilimleri vs. ötesine geçmemektedir. Diğer yandan ses kirliliği ve gürültü kontrolü kavramları, özellikle akademik boyutta gittikçe bütünsel yaklaşımla ele alınan 'İşitsel Peyzaj Planlaması' (Soundscape Planning) kavramına evirilmektedir. Şimdiye kadar çoğu şehir planlama yönetimi pratiği, gürültü kontrolü yaklaşımı kapsamında gürültü frekansı ağırlıklandırma çalışmalarına ve dolayısıyla salt fiziksel ölçümlere odaklanmış, sese dair insani tecrübeyi ve algısal kavramları hesaba katmadığı için yaşam kalitesini arttırma ve kullanıcıların memnuniyetini sağlamada yetersiz kalmıştır (URL-2).

Görünür o ki ses kalitesi ve mekânın algılanan ses örtüsü bilindik A ağırlıklı ses basınç seviyesi (Ölçülen ses frekanslarının insan kulağının deneyimlediği dB ses basıncına benzetilmesi için verilen belli ortalama seviye) ölçümleriyle belirlenememektedir. Dubois ve Reimbault'a (2005) göre "Belli standartlar elbette ki önemlidir ancak kentsel ve mimari projelerde faydasızdır! İnsanlar rahatsız olduğunda durumun normlara uyup uymadığına aldırmazlar! Artık duruma kalitatif odaklı bakmalıyız".

Bu kapsamda tıpkı Schafer gibi akustik ekoloji araştırmacısı Jacob Kreutzfeldt'in (2006) de değindiği üzere kentsel özgünlük, endüstrileşme sonrası artan modern / güncel seslerin frekans ve basınç ölçümü sonrası basitçe elenmesiyle / maskelenmesiyle inşa 
edilmemelidir. Akustik ekoloji ve işitsel peyzaj kavramlarından bahsederken birden fazla ses kaynağı ve çevresel etkileşim sonucunda oluşan bir işitsel ortamı, olumlu ya da olumsuz yargılardan bağımsız olarak değerlendirmek esas olmalıdır. İşitsel peyzaj planlaması, gürültüden kaynaklanan rahatsızlığın ötesinde incelenen alana özgü farklı seslerin toplam etkisini değerlendirmeye yönelik objektif, kullanıcı odaklı, katılımcı bir yaklaşımla benimsenebilir.

Birçok hükümet yönetimi yaklaşımında olduğu üzere ses politikalarında da katılımcı politika yaklaşımı benimsenmediğinden ötürü bireyler kararları etkileyememekte, üst politikalardan doğrudan etkilenmekte ve mağdur olmaktadır. Psikocoğrafya alanı kapsamında mekânın karakterini belirlemeye yönelik kullanılan ses yürüyüşleri, tam da burada bahsi geçen iki alanın (üst katmanda karar verici organlar ve pasif etkilenenler) arasındaki boşlukla ilgilenmektedir.

\subsection{Psikocoğrafya ve metodoloji olarak ses yürüyüşü}

Psikocoğrafya, 1950'lerde sitüasyonistlerin öne sürdüğü, mekânın bireye verdiği duygular üzerinden araştırma amacıyla uygulanan belli oyunsal yöntemları kapsamaktadır. Psikocoğrafya disiplininin öncülerinden Guy Debord (1996), psikocoğrafyanın bilinçli organize olmuş, organize olmamış veya kendiliğindenlik prensibiyle organize olmuş coğrafi çevrelerin, bireyin duygu ve davranışları üzerindeki etkilerini incelediğinden bahseder.

Demek oluyor ki her coğrafyanın psikolojik / psikanalitik bir yansıması bulunmaktadır ve Psikocoğrafya bu yansımaların yarattığı koku, hissetme/dokunma ve ses gibi duyularla insanın duygusu, bilinçaltı arasındaki ilişkiyle ilgilenmektedir.

Bazı oluşum ve hareketler, kent meydanlarının ve diğer kentsel alanların psikocoğrafi analizlerini yaparak mekânsal geliştirme projeleri için etkin veriler sunmaktadır. Örneğin; "urbansquares.com" oluşumu, kent meydanlarının dilini çevirmek / yorumlamak, kent morfolojisi ve kent yaşamındaki sosyal entegrasyonla ilgili asli değerlerini, semtlerin psikocoğrafi portrelerini, çıkarmak üzere kent kullanıcıları ile birlikte çalışmalar yürütmektedir. Meydanı ziyaret eden kullanıcının alana verdiği psikocoğrafi tepkiler ölçülüp ilgili veriler belediyeler ile ortak projelerde girdi olarak kullanılabilmektedir (URL-3).

Buna ilişkin çağdaş psikocoğrafya araştırma kolektifi "Urbansquares"'in de belirttiği gibi meydanlar bizlerle konuşur ve kelime dağarcıkları sanatın kompleks dilinin bir parçasıdır. Kendine özgü karakteristik özellikleri olan diyalektleri vardır. Unsurlar öznel anlamlara sahiptirler, birleşince mesaj oluştururlar (URL-4). Tam da bu noktada psikocoğrafya disiplini; peyzaj mimarisi ile zihinsel peyzaj arasındaki bağlantıyı kurmak ve mekâna ilişkin işitsel algı verileri elde etmek üzere ses yürüyüşlerini etkin bir araç olarak kullanabilmektedir.

Ses Yürüyüşü (soundwalk), akustik ekoloji uzmanı R. Murray Schafer (1977) tarafından 1960'larda ortaya atılan, mekânın işitsel peyzajını ve bileşenlerini tanımlamaya yönelik kullanılan ampirik bir yöntemdir. Bu sosyolojik yöntem insanların içinde bulundukları akustik kentsel alana dair algılarını ve deneyimlerini tanımlamaya yarar.

1970'lerde Schafer'in başlattığı World Soundscape Project çalışmasında ses yürüyüşleri işitsel peyzajı tanımlamada etkin bir deneye dayalı yöntem olarak yerini almıştır. Projede görev almış olan Westerkamp (2001), ses yürüyüşleri için "çevreyi dinleme amacıyla yapılan her türlü gezi ses yürüyüşüdür" der ve bunun, dinleyicileri 
çevredeki ses kompozisyonuna maruz bırakarak yapılan akustik bir eğitim olduğundan bahseder. Birey ve doğa ilişkisini vurgulayarak "kent yaşamında doğayla yakın temas önemli derecede azaltılmıştır. Doğa, özünde insanın hem yanında, birlikte yaşadığı, hem de mücadele ettiği rehberi / arkadaşı iken artık bunun yerine arada ziyaret edilen bir arkadaş halini almıştır" der. Ses yürüyüşlerinin de bu teması önemli ölçüde tekrar sağladığını öne sürer.

Venot ve Sémidor (2006) çalışmalarında, bir mekânda gerçekleşen aktivitelerle ilişkili olarak kentsel ses ortamında mekânla ilişkili ve memnun edici olan unsurları tespit etmek için ses yürüyüşü metodunu kullanmıştır. Yürüyüşleri belli bir zaman ile kısıtlamış (örneğin yarım saat), ses yürüyüşü sırasında ileri mikrofon sistemi ile kayıt yapmıştır. Çalışma, kayıt sırasında alınan etnografik notlar ve fotoğraflar ile desteklenmiştir. Böylece işitsel peyzajı değerlendirmek adına ses örtüsü bileşenlerini daha rahat tanımlayabilmiştir.

Venot ve Sémidor (2006) özellikle var olan kamusal mekânların rehabilitasyonuyla ilgilenen kent plancılarının kullanabilmeleri için geliştirilebilecek araçlardan söz eder; bu araçlar plancının mekânın akustik boyutunu dikkate alarak ilgili modifikasyonları öngörmesini sağlayacaktır. Metodolojileri, rehabilitasyon öncesi gerçekleştirilmesi gerekli olan ses yürüyüşlerini içerir, çünkü bu yürüyüşler orijinal alanı temsil eden işitsel peyzajı ortaya çıkaracaktır. Onlar; kent dokusunun doğası, kamusal alan morfolojisi, cephe malzemelerinin dokusu vb. unsurların, seslerin dağıtımı ve dolayısıyla ürettikleri işitsel izlenimleri üzerinde büyük etkisi olduğunu vurgularlar. DAT kaydedici ile birlikte stereofonik (binaural) mikrofon sistemi kullanılan çalışmada araştırmacı kişi bizzat ses yürüyüşçüsüdür.

Günümüzde uluslararası ölçekte ses yürüyüşleri hem artistik amaçla sanatçılar tarafından hem de- kısıtlı sayıda da olsa- mimar, şehir plancıları ve ses mühendisleri tarafından gerçekleştirilmektedir. Kullanıcı odaklı yapılan peyzaj çalışmaları kapsamında yürütülen ses yürüyüşü projelerinden bazı örnekler aşağıdaki tabloda sunulmuştur (Tablo 1). 
Tablo 1: Uluslararası ses yürüyüşü çalışmalarından örnekler tablosu (URL-5 \& URL-8).

\begin{tabular}{|c|c|c|c|c|c|}
\hline $\begin{array}{l}\text { SOUNDWALK } \\
\text { (SES YÜRÜYÜŞÜ) } \\
\text { ÇALIŞMASI }\end{array}$ & KONUM & YIL & AMAÇ & YAPILANLAR & WEB \\
\hline $\begin{array}{l}\text { Positive } \\
\text { Soundscapes } \\
\text { Project }\end{array}$ & $\begin{array}{l}\text { Manchester / } \\
\text { İngiltere }\end{array}$ & 2009 & $\begin{array}{l}\text {-Ses/Gürültü } \\
\text { kavramını yeniden } \\
\text { disiplinler arası } \\
\text { yoldan okumak, } \\
\text { işitsel peyzaj ve algı } \\
\text { ilişkisini ortaya } \\
\text { koymak } \\
\text {-'Negatif } \\
\text { ses/gürültü' odağı } \\
\text { yerine pozitif işitsel } \\
\text { peyzajın } \\
\text { planlamaya } \\
\text { entegrasyonu } \\
\text { odağını sağlamak }\end{array}$ & $\begin{array}{l}\text { Karma gruplarla } \\
\text { sessiz ses yürüyüşü } \\
\text { ve hem öncesi } \\
\text { (demografik), hem } \\
\text { yürüyüş sırasında } \\
\text { (işitsel algı-tepki) hem } \\
\text { sonrası (izlenim) yarı } \\
\text { yapılandırılmış anket }\end{array}$ & $\frac{\frac{\text { https:// }}{\text { www.s }}}{\text { alford.a }}$ \\
\hline $\begin{array}{l}\text { Vienna Soundwalk- } \\
\text { A Soundscape } \\
\text { Information System }\end{array}$ & $\begin{array}{l}\text { Viyana/Avustury } \\
\text { a }\end{array}$ & 2000 & $\begin{array}{l}\text {-Kentteki farklı } \\
\text { atmosferleri } \\
\text { bilgisayar ortamına } \\
\text { taşımak, kullanıcıya } \\
\text { sanal soundwalklar } \\
\text { ile bu atmosferleri } \\
\text { yaşatmak }\end{array}$ & $\begin{array}{l}\text { Canlı kaydedilen } \\
\text { seslerin, } \\
\text { soundmarkların } \\
\text { aplikasyon / web } \\
\text { sitesinden harita } \\
\text { üzerinden interaktif } \\
\text { yolla aktarılması. }\end{array}$ & $\frac{\frac{\text { http://fir }}{\text { ec.ifas. }}}{\frac{\text { ufl.edu/ }}{\text { hochm }}}$ \\
\hline $\begin{array}{l}\text { Silence Search } \\
\text { Project }\end{array}$ & $\begin{array}{l}\text { Roi Baudouin, } \\
\text { BXL/Belçika }\end{array}$ & 2006 & $\begin{array}{l}\text {-Kentsel tasarımcı } \\
\text { için mekandaki } \\
\text { modifikasyonlarla } \\
\text { ilgili operasyonel } \\
\text { çözümlerin parçası } \\
\text { olarak Soundwalk'u } \\
\text { kullanmak }\end{array}$ & $\begin{array}{l}\text { Ses yürüyüşü, } \\
\text { gözlem, ses } \\
\text { mühendisleriyle } \\
\text { incelemeler ve } \\
\text { akustik çalışmalar } \\
\text { sonrası park } \\
\text { zeminindeki tümseğin } \\
\text { arttırılarak parktaki } \\
\text { gürültüsü ve trafik } \\
\text { sesinin azaltılması }\end{array}$ & $\frac{\frac{\text { http://pl }}{\text { ea- }}}{\frac{\text { arch.or }}{\text { gl }}}$ \\
\hline $\begin{array}{l}\text { A Case Study Of } \\
\text { The Soundscape of } \\
\text { Loreta Square In } \\
\text { Prague }\end{array}$ & $\begin{array}{l}\text { Prag / Çek } \\
\text { Cumhuriyeti }\end{array}$ & 2006 & $\begin{array}{l}\text {-Loreta } \\
\text { Meydanı'nda hangi } \\
\text { sesle işitsel peyzaj } \\
\text { öğesi olma } \\
\text { özelliğine sahiptir? } \\
\text { sorusuna yanıt } \\
\text { verme } \\
\text {-Loreta } \\
\text { Meydanı'nda } \\
\text { dinleyici-ses ve } \\
\text { çevre arasında } \\
\text { tanımlanabilir } \\
\text { ilişkileri ortaya } \\
\text { çıkarma }\end{array}$ & $\begin{array}{l}\text { Karma gruplarla } \\
\text { sessiz ses yürüyüşü } \\
\text { ve sonrası } \\
\text { yapılandırılmış anket }\end{array}$ & $\begin{array}{l}\text { is.cuni. } \\
\mathrm{CZ}\end{array}$ \\
\hline
\end{tabular}

Ses yürüyüşü metodolojilerinin kentsel gelişim uzmanlarınca nasıl kullanabileceğini basit bir örnek ile Brüksel'de yer alan Roi Baudouin Parkı'nda toprak höyüğünün etkinliği yardımıyla açıklanabilmektedir (Venot \& Sémidor, 2006). Burada, tıpkı görsel hafıza için fotoğraf kullanılması gibi işitsel hafızayı belirlemek için ses yürüyüşleri kullanılmıştır. Elde edilen kalitatif ve kantitatif veriler alanın analizinde, tıpkı mimari verilerin alanın morfolojik yapısını belirlemesindeki gibi çok etkili olmuştur. Kullanıcıların algı verilerinin ışığında parktaki höyüğün yüksekliğini arttırmışlar, mevcut orta ve yüksek frekans aralığına ve toprak höyüğün arkasındaki alana hizmet eden verimli bir gürültü bariyeri oluşturmaya ön ayak olmuşlardır (Şekil 1). 


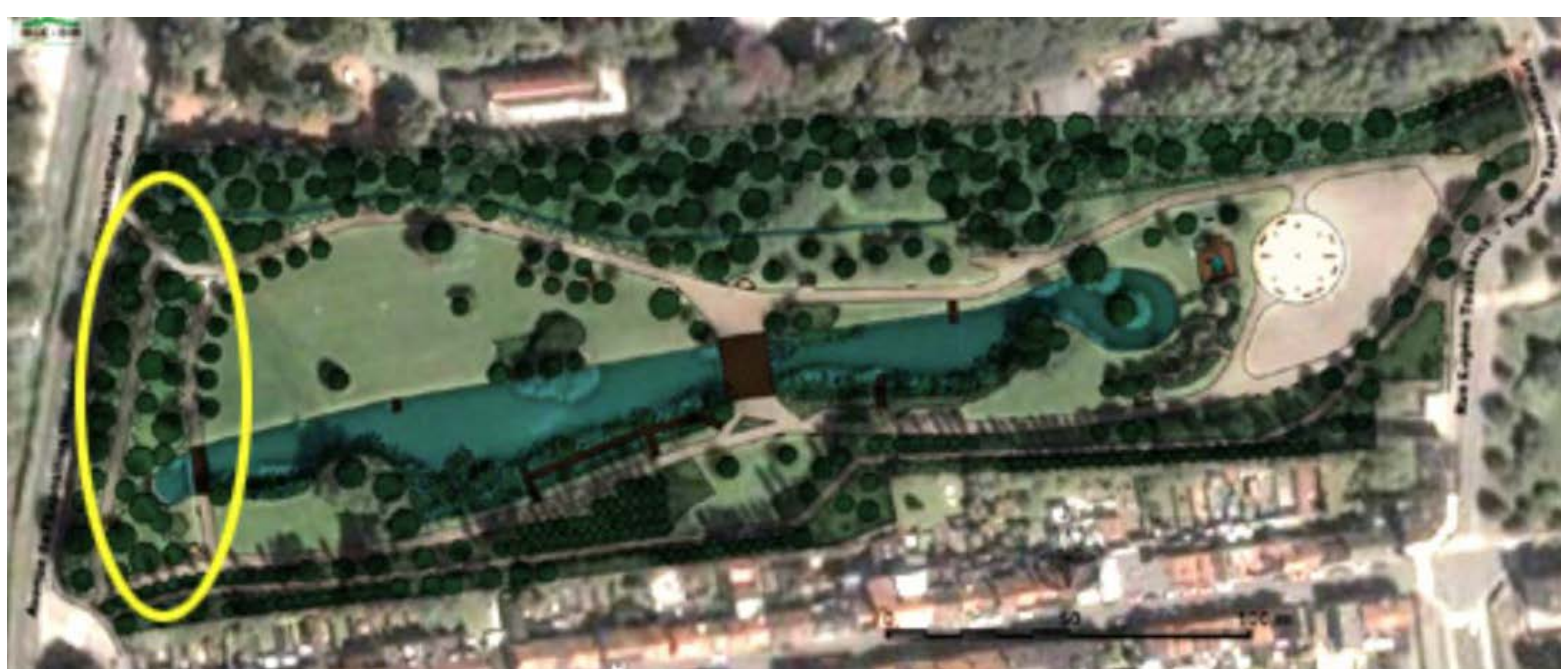

Şekil 1: Roi Baudoin parkı haritası ve işitsel peyzajına ilişkin müdahale alanı (Venot \& Sémidor, 2006)

Tüm bu çalışmalar ses yürüyüşünün, ya kişilerin çevrelerindeki kentsel işitsel peyzaj üzerine düşünmelerini sağlayan bir yol ya da araştırmacıların işitsel peyzajı kentsel dokuyla ilişkilendirerek değerlendirdiği bir yöntem olarak kullanıldığını göstermiştir. Özellikle uzmanlarla yapılan ses yürüyüşlerinin, kentsel tasarım ve gelişim alanlarında çalışan profesyonellerle iş birliği yapma yolunda öğretici bir yol olduğu görülmüştür. Metodolojinin yenilikçi doğası daha önceki çalışmalarında kentsel mekânın ses boyutu üzerinde düşünmemiş olan profesyonellerin ilgisini çekmiştir. Daha önce bahsedildiği üzere, düzenleyici yönüyle ses kontrolü çalışmaları biliniyor olsa da niteliksel anlamda psikocoğrafi algı verilerini kullanan bu yöntem çoğu için yenilikçi bir yaklaşım olmuştur. Birlikte yapılan ses yürüyüşlerinde araştırmacı ve katılımcıların kentsel mekânda keşif yaparken paylaşılan duyusal bir deneyim yaşamaları mümkün olabilmekte, böylelikle belki diğer araştırma araçlarına göre daha derinlemesine ve daha anlamlı, katılımcılık boyutuna sahip yarı-yapıı anketler kullanılabilmektedir.

Bir derin dinleme pratiği olan bu anket çalışmalarının tasarımında, işitsel peyzajı algılama deneyimini daha da derinleştirmek amacıyla bazen geçici olarak görme duyusu engellenerek duyma duyusu güçlendirilebilmektedir. Kanada'nın önde gelen Milli Toprak Koruma Örgütü- Nature Conservancy Canada (NCC); toprağı, coğrafyayı ve işitsel alanı derinlemesine kavrayabilmek amacıyla ses yürüyüşü çalışmalarının gözü kapalı biçimde yapılmasını önermektedir. NCC'ye göre ses yürüyüşlerinde göz kapalı olduğunda mekân kullanıcısı, kendi konfor alanından çıkmaktadır. Gözle görüşü devre dışı bırakmak, yürüyüş deneyiminin etkisini büyük ölçüde güçlendirerek işitme ve dokunma duyularına güvenmeyi gerektirmektedir. Bazı insanlar gözleri kapalıyken özellikle korunmasız hissedebilmektedir, ancak bu durum yoğunlaşmış bir konsantrasyonla birlikte, doğayla yeni ve farklı türden bir iletişim kurmaya izin vermektedir (URL-9).

Görme engelli bireyler çoğu zaman yetenekli dinleyiciler olarak bilinmektedir. Tüm duyularını kullanabilen insanların fark edemediği birçok ses verisini algılayabilmektedirler, çünkü çoğu kez görme yeteneği olanlar görsel veriyi algılamaya çok fazla konsantre olmaktadırlar. İşitsel peyzaja ilişkin farkındalığı arttırmak için geçici olarak görsel "gürültüyü" bloke etmek, araştırma deneylerinde bir yöntem olarak kullanılabilmektedir. 


\section{SAHA DENEMELERI}

Saha denemeleri kapsamında çalışmaların ana eksenine oturan "Kadıköy_AKUSTiK" işitsel peyzaj araştırma çalışmasının yanı sıra; Kadıköy_AKUSTİK projesini desteklemesi amacıyla "1. FAZ Pilot Proje: Ekinlik Adası Ses Yürüyüşü" ve "istanbullu Çocukların Doğaya ve Kente Uyumu- TÜBITAK 4004 Projesi Kentin Sesleri" isimli alt çalışmalar yürütülmüştür.

\subsection{FAZ Pilot proje: Ekinlik Adası ses yürüyüşü}

Kadıköy Meydanı'nda yapılması planlanan Kadıköy_AKUSTiK çalışmasından önce Marmara Bölgesi, Balıkesir iline bağlı Avşa Adası'nın karşısında bulunan Ekinlik Adası'nda, işitsel peyzaj araştırmasının önemli bir araştırma aracı olan ses yürüyüşü gerçekleştirilerek küçük bir pilot çalışma yapıımıştır. 2013 Eylül ayı içerisinde yapılan çalışma; adanın batı yakasındaki ses örtüsüne ilişkin algıyı incelemek amacıyla yapılan ses yürüyüşü, anket ve gözlem çalışmalarını içermiştir.

Ses yürüyüşünün rotası, adanın batı sahili (Voli) ile Köy Meydanı arası olup toplam yol tek yön, 3 km'lik mesafeyi kapsamaktadır (Şekil 2). Yürüyüşe 4 ada ziyaretçisi katılmıştır.

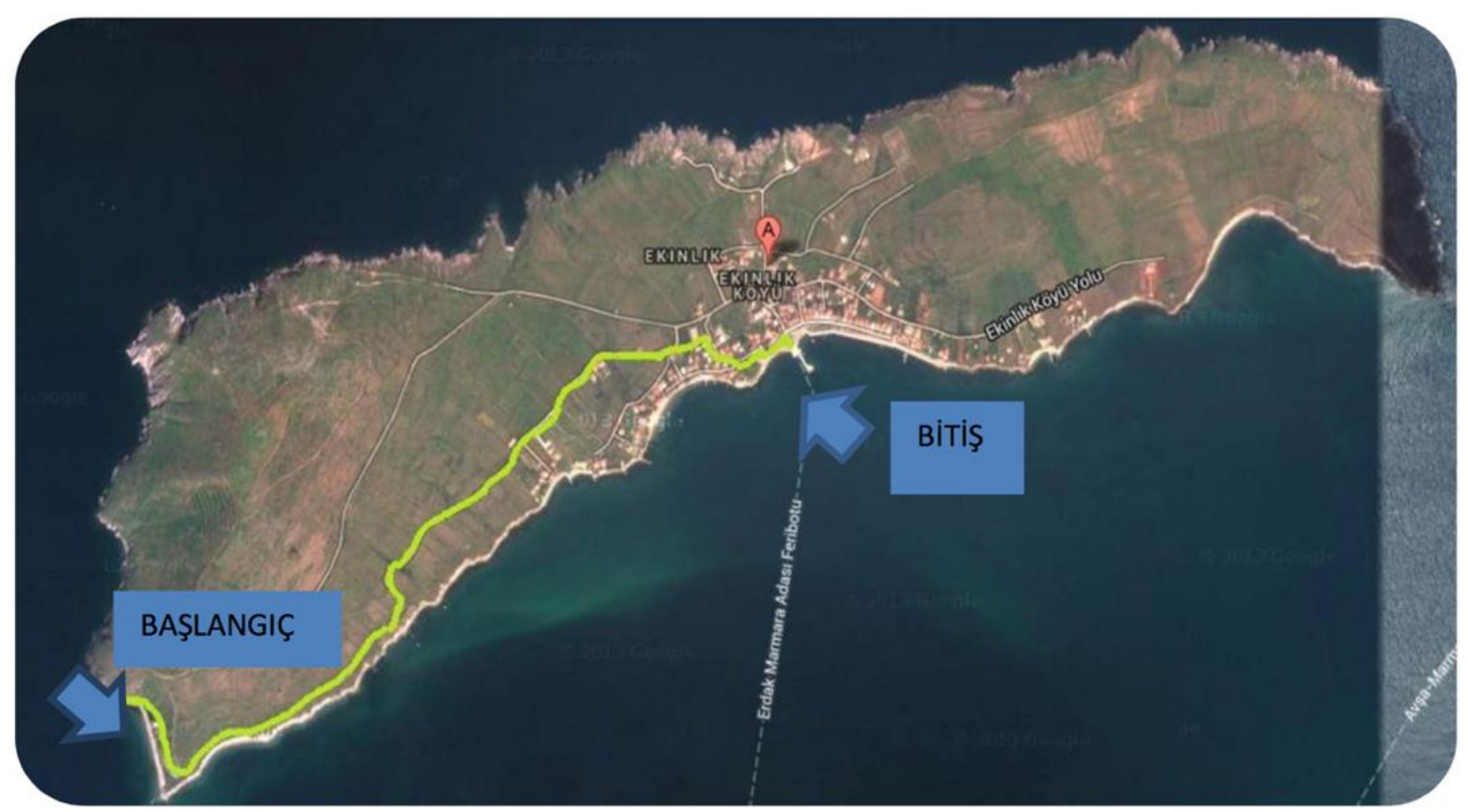

Şekil 2: Ekinlik Adası Google harita görseli üzerinden çizilen ses yürüyüşü rotası (Yazar tarafından hazırlanmıştır.)

Ses Yürüyüşü, katılımcılara rehberli eşlik edilerek, sessiz ve katılımcının gözleri kapalı olacak şekilde, 45 dakikada gerçekleştirilmiştir. Yürüyüş, sonrası katılımcılarla sohbet edilmiş, basit ve temel sorular yöneltilmiştir. Bu sorular aşağıdaki gibidir:

1. Ses yürüyüşü yapılan yer ve rota ile ilgili hisleriniz nelerdi?

2. Sevdiğiniz ve sevmediğiniz, sizi rahatsız eden üç ses neydi?

3. Bu işitsel peyzajda neyi değiştirirdiniz? 
Anket ve gözlem sonrası yapılan tespitler şu şekildedir:

- Ses yürüyüşü, mekânın topoğrafyasının daha net algılanmasını mümkün kılmıştır.

- Mekân ve rota, doğal ve rahatlatıcı ama tekinsiz bir hisse sahiptir.

- Adapte olamama hissi mevcut olup, mekâna özgü sembol sesler (soundmark) eksik bulunmuştur.

- Rüzgârın gücü yüksek olduğu için diğer ses unsurlarını örtmüştür.

- Merkezdeki habitat ve insan sesleri, mekâna ilişkin daha canlı ve güvenli hisler vermesi itibariyle pozitif bir algı yaratmıştır. Bu ses örtüsünün sessiz-tekinsiz algılanan yerlerde de var olması (batı yakası) tercih edilmektedir.

- Metalik-teknolojik sesler az olsa da rahatsızlık vermiştir. Doğal sesler tercih edilmiştir. (Cır cır böceği, su sesi, ayak sesleri, hafif rüzgâr...)

Bu küçük ölçekli pilot çalışmasının araştırmaya önemli katkıları olmuştur (Fotoğraf 1). Çalışma sayesinde Kadıköy_AKUSTIKK kapsamında ses yürüyüşünün uygulanışına yönelik teknikler görülmüş, öğrenilmiştir. Anket sorularına verilen cevaplardan yola çıkılarak daha başka, ayrıntılı anket soruları çıkarılmıştır. Ayrıca daha başka hangi gruplarla anket ve gözlem yapılması gerektiği görülmüştür. Bunun dışında araştırmanın başlangıç noktasında hipotezden çok verinin önemli olduğu görülmüştür.

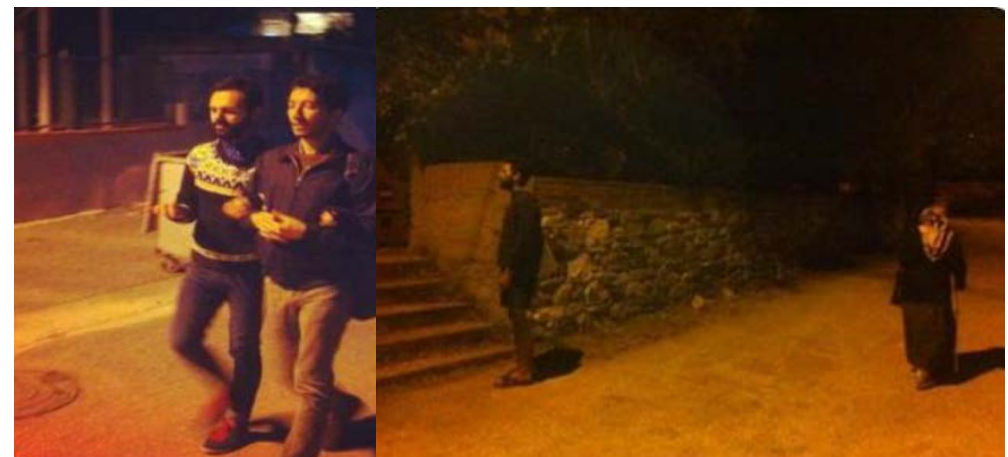

Fotoğraf 1: Ekinlik Adası ve rehberli ses yürüyüşü ile ilgili örnek resimler (Fotoğraf: Oğuz Öner)

\subsection{Kadıköy_AKUSTIKK ses yürüyüşü ve atölye çalışması denemesi (ITÜ BAP Projesi ve IKSV 4. Tasarım Bienali çalışması)}

\subsubsection{Amaç}

Günümüzde Kadıköy gibi metropoliten alanların sahip olduğu şehir karmaşası içerisinde mevcut ses kaynaklarının algısı net olarak fark edilmese de şehirlerin ses örtüsünün de varlığı ve bu varlık içerisinde şehir yaşamının sürdürülmeye çalışıldığı yadsınamaz bir gerçektir. Şehir yaşamının ses örtüsü ve işitsel peyzaj ile entegre bir şekilde planlanarak, yaşam alanının kalitesinin artırıması ise şehrin sahip olduğu ses varlığının dikkate alınarak, kullanımların buna göre belirlenmesi ile mümkün olabilecektir. Bu planlamalarda kullanıcıların algısı ve istekleri de yapılan planlama çalışmalarında önemli veri kaynağı olarak görülmektedir.

Kadıköy Meydanı'nda gerçekleştirilmekte olan "Ses Yürüyüşü ve Ses Atölyeleri" ile ilçenin sahip olduğu işitsel peyzajın farkındalığı ve genel itibariyle şehirlerdeki ses algısının, mekân tasarımında etkili olabileceği bilinci katılımcılara edindirilmeye çalışılmaktadır. Atölye yeri olarak Kadıköy Meydanı'nın seçilme nedeni ise mekânın içinde birçok fonksiyon bulunması, geçiş-transfer odağı olması ve meydan kullanımı nedeni ile kulanım yoğunluğunun fazla olmasıdır. Meydanın sahip olduğu mekânsal öğeler, bu mekânın ses kaynağı çeşitliliğini zenginleştirmiş ve ses örtüsünü 
çeşitlendirerek farklılaşmasına imkân sağlamıştır. Tüm bu özellikleri ile Kadıköy Meydanı gerçekleştirilmekte olan ses çalışmaları için en uygun mekânlardan biri olarak düşünülmüştür.

\subsubsection{Tanım, yöntem ve uygulama}

Proje; ITÜ Bilimsel Araştırma Projeleri kapsamında yürütülmüş² ${ }^{2}$ İKSV Tasarım Bienali ve Tasarım Atölyesi Kadıköy (TAK) iş birliğiyle gerçekleştirilmiştir. Bu kapsamda ilk ses yürüyüşü için öncelikle Mimarlık Fakültesi öğrencilerine çağrı yapılmış olup diğer iki ses yürüyüşü için İKSV Tasarım Bienali kanallarıyla genel katılımcıya açık çağrı yapıımıştır (Fotoğraf 2). İlk yürüyüşün Mimarlık Fakültesi öğrencileri ile yapılmasının nedeni öğrencilerin mekânı ve kenti okumaya yönelik bilgi altyapısı, alışkanlığı ve tecrübesi olmasıdır. Diğer çalışmalarda ise farklı profillerden oluşan farklı katılımcılardan veri akışı sağlanabilmiştir.

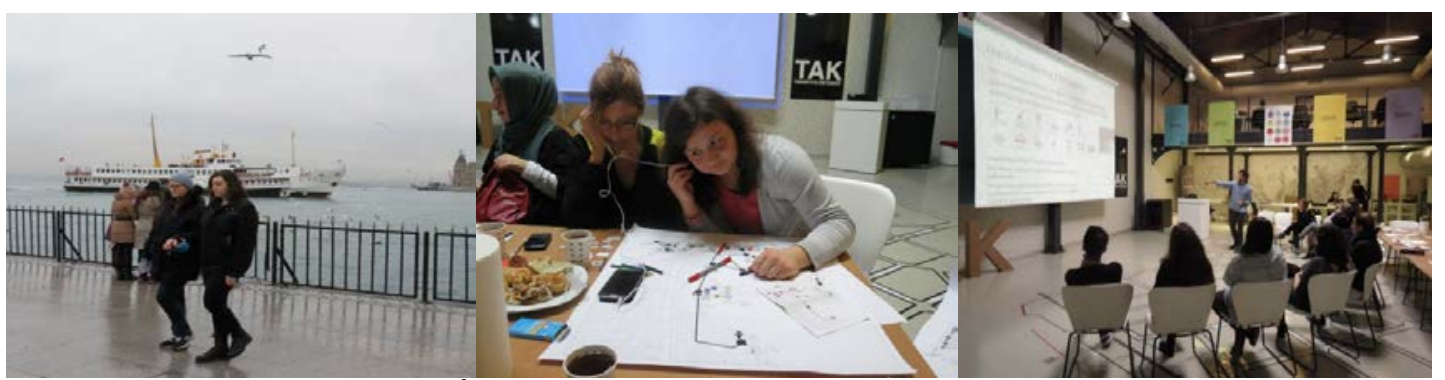

Fotoğraf 2: Kadıköy_AKUSTİK ses yürüyüşü, haritalama ve sunum çalışmalarından görüntüler (4. Tasarım Bienali, 2014)

Katılımcıların yürüyüş deneyimleri, eğitimli rehberler eşliğinde gözü kapalı gerçekleştirilmiştir. Sadece meydan içinden yürümek, kentsel alanı dinlemek, duyulana dikkat vermek ve yapılı çevre, kentsel altyapı, meydan tasarımı ve işitsel peyzaj ile ilgili bazı sorulara yanıtlar vermek; mekânsallığa yönelik ötelere kadar uzanan bir inceleme sunmuştur. Farklı ses örtülerine sahip sokaklardan, açıklıklardan, kapalı alanlardan geçmek, katılımcının daha önceden duymadığı / dikkat etmediği çeşitli- üstü kapalı ya da belirgin- işitsel peyzaj unsurlarına kulaklarını açmalarını sağlamış, bu unsurların meydanın ilerideki yeni kentsel tasarım planı açısından ne kadar önemli olabileceğine dair bir tartışmaya katılımcıları dâhil etmiştir.

Katılımcılar gözleri kapalıyken sesler dışında koku, ışık, hacim ve doku (zemin ve duvarlar) ilişkin geri dönüşlerde de bulunabilmektedir. Bu veriler mekânın planlaması açısından çok değerli olsalar da ses yürüyüşünde esas olarak duyulan ve algılanan akustik verilere ve hislere odaklanılmıştır.

Katılımcıların ses kaydının yanı sıra rotada duyulan genel ses örtüsünün kaydı için stereo mikrofonlu Hi-Fi (High Fidelity) ses kaydı, video ve fotoğraf kaydı yapıımıştır.

Bir saatlik yürüyüşün ardından eğitmenler ile birlikte Kolektif Yaratıcı Zihin Haritası çalışması (Collective Creative Mind Map) gerçekleştirilmiştir. Ardından Bireysel Ses Haritası çalışmaları yapılmıştır. Bu çalışmada katıımcılar rehberleriyle birlikte gezdiği duraklarda alınan ses kayıtlarını kulaklıklarla dinleyerek, o durağa ilişkin duyduğu sesleri ve hissettiklerini ikon etiketleriyle pafta üzerinde belirlemişlerdir (Harita 1).

\footnotetext{
${ }^{2}$ Araştırma, projenin baş danışmanı İTÜ Şehir ve Bölge planlama Bölümü öğretim üyesi Prof. Dr. Özlem Özçevik yönetiminde gerçekleşmektedir.
} 


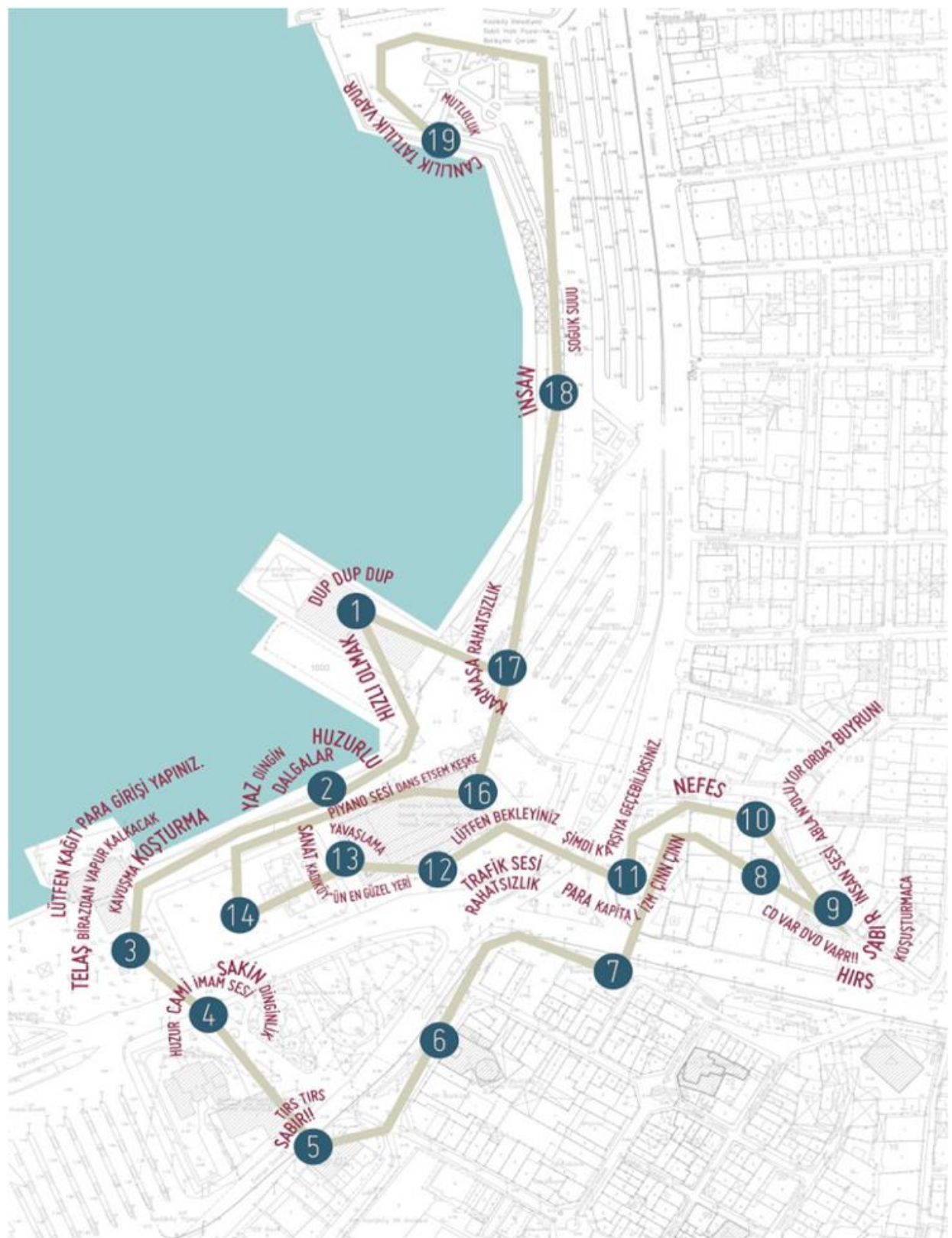

Harita 1: Kadıköy ses yürüyüşü rotasını gösteren, ses duraklarında duyulan seslerin ve algılanan hislerin görselleştirildiği kolektif zihin haritası (Yazar tarafından hazırlanmıştır.)

Ses yürüyüşünün ardından uygulanan bu iki analitik haritalama metoduyla mekâna ait bilgi, düşünce, bilinçaltı çağrışım, his verileri bütünüyle açığa çıkarılmış; katılımcı bir yolla mekânın okunması ve yazıımasının pratiği yapılmıştır.

Meydandaki işitsel peyzaja ilişkin katılımcıların açığa çıkardığı duygu/his verilerinin gruplandırılması için Andringa \& Lanser (2013) tarafından geliştirilen Olaylılık / Keyiflilik (Eventful / Pleasent) modelinden yararlanılmıştır (Şekil 3). Bu modele göre duygular iki boyutlu alana dağıtıır. Uyarılma, dikey aksı (yüksek olaylılık-alçak olaylılık), yatay aksı (keyifli algı - keyifsiz algı) yansıtmaktadır. 


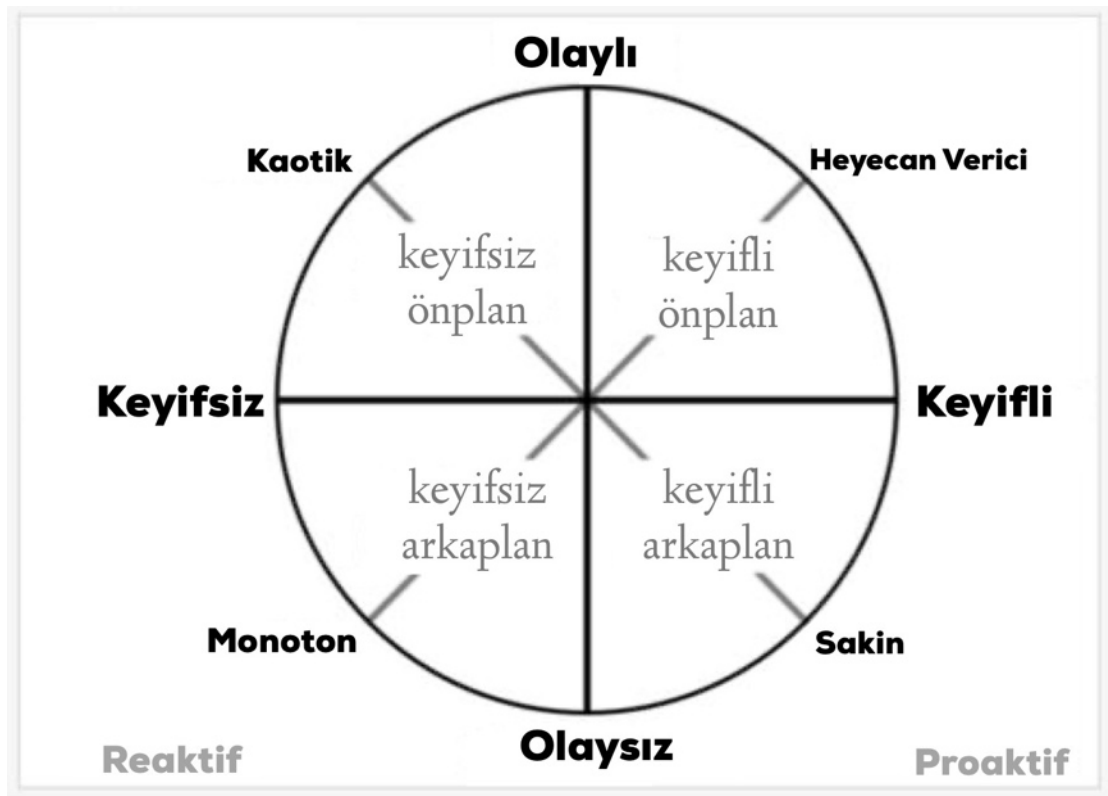

Şekil 3: Olaylılık / Keyiflilik Modeli (Andringa \& Lanser, 2013)

Aşağıda Olaylıık / Keyiflilik modelinin Kadıköy_AKUSTíK çalışması his verilerine uyarlanışını gösteren şemada duygusal verilerin dağıtılığı dört çeyrek oluşmaktadır (Şekil 4). Düşük değerlikteki hisler 1 ve 3 . çeyreklerde (quadrant alanında) yer almaktadır ve katılımcıların istenmeyen his verilerini göstermektedir. Sentez his haritasında bu çeyrekler belli duraklardaki baskın /çoğunluğun bildirdiği baskın his verilerini yansıtan gruplamalardır.
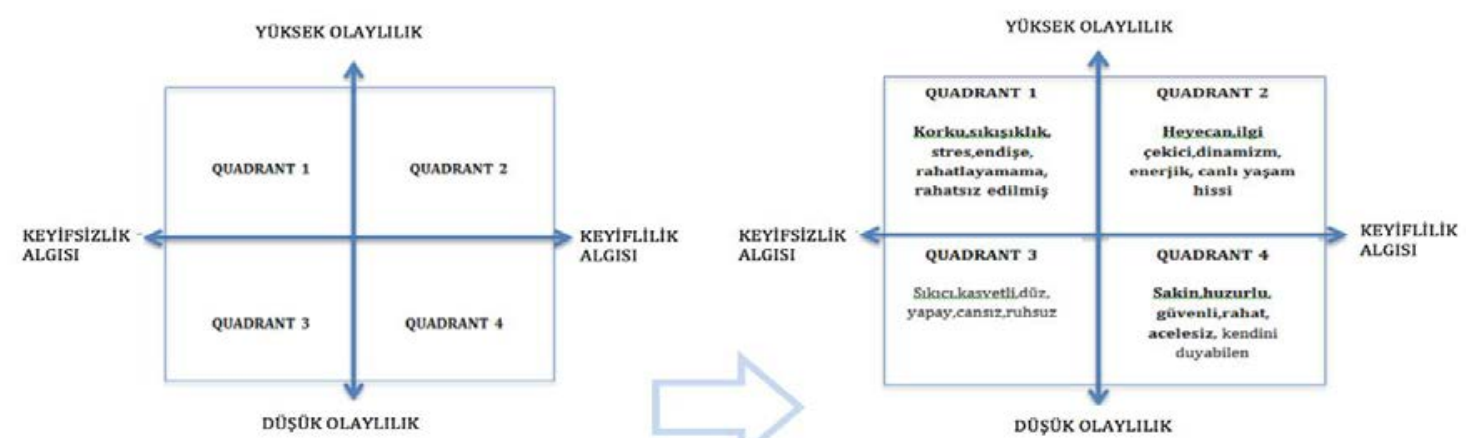

Şekil 4: Andringa \& Lanser (2013) tarafından geliştirilen Olaylılık / Keyiflilik Modeli (Eventful / Pleasent Model) ve bu modelin Kadıköy_AKUSTiK çalışması his verilerine uyarlanması (Yazar tarafından hazırlanmıştır.)

Kadıköy Meydanı'nda gerçekleşen ses yürüyüşü ve sonrasında katılımcıların her mekânda duyumsadıkları hislerine ilişkin etiketler, çeyreklere kalın (bold) yazılı sözcüklerle dağıtımıştır. Kadıköy Meydanı'nda 1, 2 ve 4. çeyreklere iliş̧kin his verileri mevcut olup 3. çeyreğe yönelik herhangi bir his verisi gözlemlenmemiştir. Bu hissel verilerin çalışma alanında hangi kamusal mekân noktalarına ve duraklara karşılık geldiği haritalara işlenmiş, mekândaki sıkışık bölgeler ve rahatlama bölgeleri haritalarla görselleştirilmiştir. 


\subsubsection{Hedeflere Yönelik Değerlendirmeler}

Kadıköy Meydanı gibi kamusal alanların okunabilir ve rahat kullanılabilir alanlar olması için işitsel peyzaj ve akustik ekoloji incelemeleri, çalışmaları ve müdahaleleri yapılarak kullanıcının mekân ile ilişkisinin katılımcı yöntemle sorgulanması ve uzun süreçte kullanıcı-mekân iletişiminin güçlenmesi öngörülmüştür. Buna yönelik olarak katılımcılarla bir tür derinlemesine anket ve gözlem çalışması olan ses yürüyüşü ve haritalama çalışmaları yapılmış, mümkün olduğunca objektif bakış açısıyla ses kaynakları ve his gruplaması gerçekleştirilmiştir. Bu sayede kentsel mekânın korunması / mekânın yeniden planlanmasına yönelik stratejilere yön vermek ve planlama disiplinine tek taraflı ses kontrolü yaklaşımlarının ötesinde katılımcı, bütüncül ve doğrudan kullanıcı odaklı bir katkı sağlanması hedeflenmiştir.

Çalışma sayesinde kullanıcılarla birlikte spesifik olarak hangi noktada hangi alt (dip) seslerin ve üst seslerin duyumsandığı, hangi seslerin öne çıkabileceği veya arkada kalabileceği, hangi ses kaynaklarından rahatsız olunduğu veya memnun olunduğu; deniz, kuş (martı), klasik müzik (konservatuar), ezan, tramvay, vapur, sokak müzisyenleri gibi ses kaynaklarından hangilerinin korunması / yaşatılması / güçlendirilmesi gerektiği gibi değerlendirmeler yapılmıştır. Bu değerlendirmeler, mekânın kimliğinin güçlendirilerek karakterinin ortaya çıkarılması ve bu sayede kullanıcıyla sağlıklı biçimde "konuşabilmesi" açısından önem taşımaktadır. Proje, kent kullanıcısının yaşam kalitesinin artırımasında ve mekâna ilişkin aidiyet duygusunun güçlendirilmesinde de etki yaratarak uzun vadede sosyo-akustik açıdan bireyin yaşamına pozitif katkı sağlamayı hedeflemiştir.

Sentezlenen verilerin niteliği ve niceliği sesin, düşünüldüğünden daha kompleks bir mekânsal unsur olduğunu ortaya koymaktadır. Planlama ve tasarım sürecinde ses unsuru, daha baskın olan görsel estetik unsuruyla (ve hatta koku estetiği ile) entegre biçimde etkin olarak değerlendirilebilmelidir. Bu çerçevede akustik unsurların planlamatasarım süreçlerine katılımcı yöntemlerle nasıl dâhil edilebileceğine ilişkin çalışmalar literatürde çok az sayıdadır. Kadıköy_AKUSTIK çalışması da kentsel planlama-akustik algı arasındaki bu boşluğu ses yürüyüşü yöntemiyle doldurabilmeyi hedeflemiştir.

Çalışmada işitsel peyzaj kavramı ele alınırken, akustik bir çevredeki olumsuz bileşenlerin yönetimiyle ilgilenilerek açık alanlarda mekân kullanıcısı tarafından değer atfedilen noktalara olumlu vurgu yapılmıştır. Kang'ın değindiği gibi işitsel peyzaj çalışması insanların akustik tercihlerini pasif olarak anlamakla değil, tıpkı kentsel kamusal alanların tasarım süreci gibi maksatlı tasarlanmış bir süreci yönetmekle ilişkilidir (Kang 2006). İşitsel peyzaj, plancılar ve mimarlar tarafından meydanlar, parklar, alışveriş merkezleri, tarihi miras alanları gibi birçok farklı mekânın erken tasarım etaplarında veya yeniden geliştirildiği, düzenlendiği süreçlerde kolayca devreye girebilmektedir (Brown, 2011). Kadıköy_AKUSTiK projesi de Kadıköy Meydan alanına odaklanılmış katılımcı bir işitsel peyzaj çalışması olması itibariyle kentsel tasarımcılara ve plancılara bir tür "ön kılavuz" oluşturmayı hedeflemektedir.

Akustik niteliği olan açık alanların tasarımı için bazı işitsel hedeflerin belirlenmesi gerekmektedir. Bu prensipleri devreye sokmaya yönelik açık alan tasarımı sürecindeki adımlar Brown \& Muhar'ın (2004) çalışmasından yararlanılarak aşağıdaki şemada gösterilmiştir (Şekil 5). 


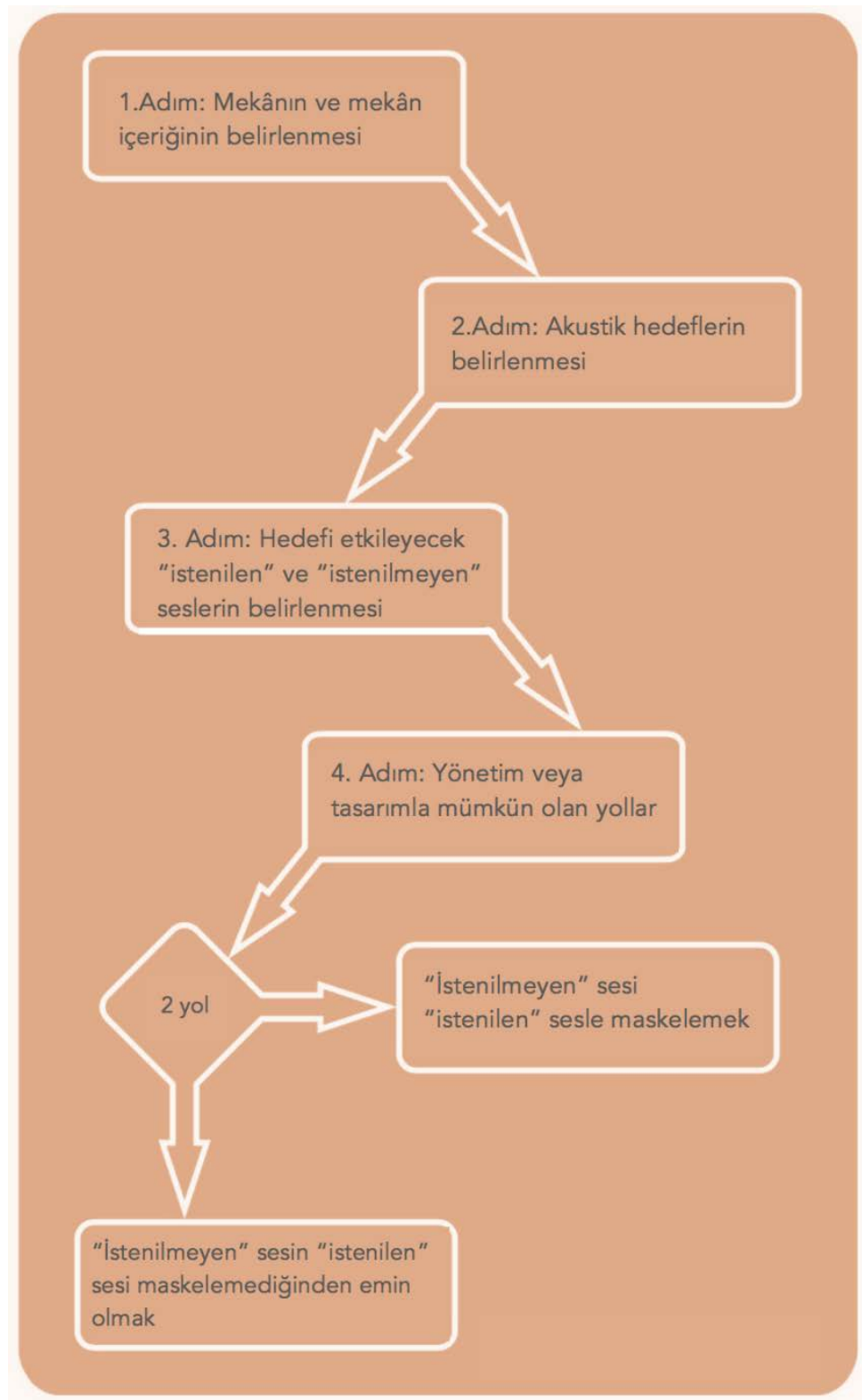

Şekil 5: Akustik açık alanların tasarımında izlenen adımlar. (Brown \& Muhar, 2004'den uyarlanmıştır.)

Özetle adım 1, net bir biçimde ilgi duyulan mekânın ve mekân içeriğinin belirlenmesidir; Mekânla iliş̧ili kişiler kimdir, ne yaparlar? Yoğun-yoğun olmayan kullanım saatleri nedir? Hava koşulları, mekâna ilişkin beklentiler nedir. . . gibi).

Adım 2, akustik hedeflerin belirlenmesine yöneliktir. Bu süreç, plancıların odak gruplar veya mekânda yaşayanlarla ortak hedefe varmaları sürecine benzetilebilir. Burada intiyaçlara yönelik hedeflerin belirlenmesi esastır. Akustik hedefler arasında; "akan suyun baskın ses olarak belirlenmesi, doğal seslerin duyum kalitesinin arttırılması, insanların birbirini duyabilmesi, ikonik kimlik seslerin baskın olması" örnek olarak gösterilebilir.

Adım 3, katılımcılarla birlikte istenilen seslerin ve istenilmeyen seslerin belirlenmesi sürecidir. Gürültü kontrolü yaklaşımındaki belli $\mathrm{dB}$ üstündeki seslerin kısılması / kesilmesi pratiğinden farklı olarak tercih edilen sesler, rahatsız olunan sesler 
saptanmaktadır. Birlikte yapılan anket, ses yürüyüşü gibi katıımcı yöntemlerle, ilgili mekânda hangi ses kaynaklarının güçlendirilebileceği, zayıflatılabileceği, maskelenebileceği vb. kararlaştırılmaktadır.

Plancılar, ilk üç adımı tamamladıkları takdirde akustik tasarım ve yönetim süreci için tüm fırsatları araştırmak ve uygulamaya koymak adına akustik uzmanlar görevlendirmektedir. Uzmanlar bu aşamada gürültü kontrolü ve akustik tasarımda devreye giren beceri ve araçları kullanarak istenilen ve istenmeyen seslerin dengelemesini yapmaktadır. Burada özetle ya istenilen sesin istenmeyen sesin önüne geçmesi sağlanmakta, ya da istenmeyen sesin istenilen sesin önüne geçmesi engellenmektedir (Brown \& Muhar 2004; Brown, 2011).

Kadıköy_AKUSTIKK projesinde bu adımlardan ilk üçüne yönelik çalışma denemeleri yapılmıştır. İlk adımda mekân olarak meydan ve meydan bileşenleri belirlenmiş, kullanıcıların demografik bilgileri kaydedilmiştir. Ardından ön anket çalışmalarıyla Kadıköy Meydanı işitsel peyzajına yönelik kullanıcıların hayalleri, neleri değiştirmek isteyebilecekleri, ne tür sesleri arzuladıkları, uzun vadede ne tür bir işitsel alan duymayı hedefledikleri sorulmuştur. Daha sonraki adımda ise derinlemesine anket çalışması olarak ses yürüyüşü çalışması, kolektif zihin haritası, etiket bulutları ve ses algı haritası çalışmaları yapılmıştır. Bu çalışmalarla katılımcıların intiyaçları ve beklentileri daha derinlemesine analiz edilerek tercih edilen ve edilmeyen sesler, çağrıştırdıkları hislerle birlikte somut bir şekilde belirlenmiştir.

\section{3. İstanbullu çocukların doğaya ve kente uyumu; TÜBITAK 4004 Projesi, "Kentin Sesleri" çalışması denemesi}

Marmara Üniversitesi Kent Sorunları ve Yerel Yönetimler Araştırma ve Uygulama Merkezi (KEYEM) bünyesinde ${ }^{3}$, TÜBITAK destekli "İstanbullu Çocukların Doğaya ve Kente Uyumu" adlı proje kapsamında "Kentin Sesleri" çalışması yapılmıştır. Kadıköy_AKUSTIKK projesinin devamı niteliğinde olan çalışmada Üsküdar, Ümraniye, Kağıthane ilçelerinde bulunan ortaokul 5. ve 6. sınıf öğrencileri ile çalışılmıştır.

Yönetilemeyecek boyutta gelişen kentleşmenin sonucunda, doğadan hızla uzaklaşan çocuklar, dış ortamda kuralların olmadığı mekânlarda kendi doğallığında oynamak yerine kapalı mekânlarda kalıplaşmış, çoğunlukla bireysel oyunlar oynamaktadırlar. Engel olunamayan bu sürece biraz farkındalık katmak ve onları doğaya kazandırmak, kentte doğal ortamlarda hem birbirleriyle hem farklı kentsel mekân türleriyle tanışmaları için bu proje kapsamında çeşitli atölye ve etkinliklerde kentli çocuklara 12 ay boyunca eğitim verilmiştir (Fotoğraf 3 ).

\footnotetext{
${ }^{3}$ Proje Yürütücüsü Doç.Dr. Yasemin Çakırer Özservet, Marmara Üniversitesi KEYEM Direktörü
} 


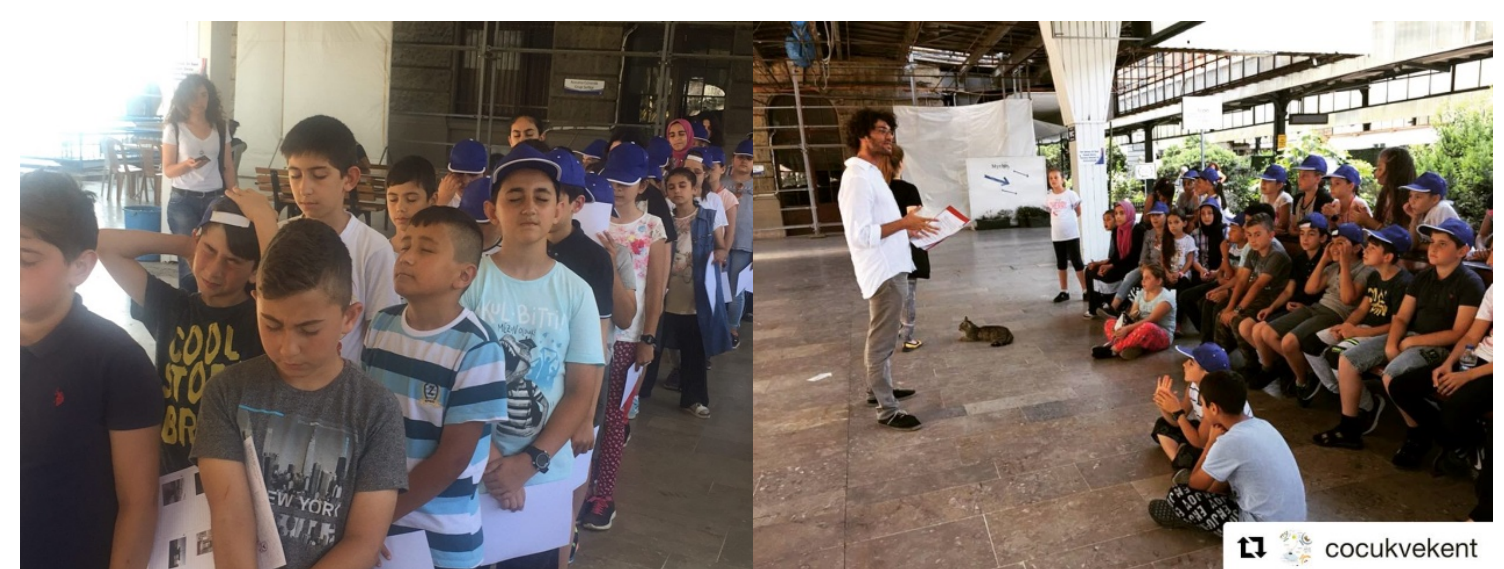

Fotoğraf 3: TÜBITAK 4004 Projesi, "Kentin Sesleri” çalışması denemesi, ses yürüyüşü görüntüleri, Temmuz 2018 (Fotoğraf: Oğuz Öner)

Proje katılımcısı çocukların "Kentin Sesleri" çalışması ve diğer sanat atölyeleri sonrası kentsel doğal alanlarda kendini ilişkilendirmesi, geleceklerini sağlıklı inşa etmesi için yaşadıkları kentin doğasıyla, mekânsal dokusuyla ve toplumsal yaşamıyla uyum sağlaması hedeflenmiştir. "Kentin Sesleri" çalışması kapsamında her üç ilçeden toplam 90 çocukla birlikte, üçer gruplar ile ses atölyeleri gerçekleştirilmiştir. Kadıköy_AKUSTíK projesinin deneyimiyle ve daha mikro ölçekte, basitleştirilmiş haliyle çocuklarla ses yürüyüşü ve zihin haritalama çalışmaları uygulanmıştır. Bu çalışmada da ilçenin sahip olduğu işitsel peyzajın farkındalığının ve kentlerdeki ses algısının, mekânı okumada, kentlerde rahat yaşam alanı oluşturmada ve daha ileriki aşamalarda mekânların tasarımında etkili olabileceği bilinci çocuklara edindirilmeye çalışılmıştır. Çalışma alanı olarak bu kez Haydarpaşa Garı çevresine odaklanılmıştır. Bu alanın seçilme sebepleri, çocukların gözü kapalı yürüyüşü için belirlenen rotada (Harita 2) trafik akışının olmayışı ve dolayısıyla alanın güvenli oluşu, Kadıköy Meydanı'nın sembol seslerine (deniz, martı, vapur gibi) doğrudan erişimin olması ve geçirdiği yangın sonrası inşaat sürecine giren Haydarpaşa Garı'nın dönüşüm öncesi sahip olduğu işitsel peyzajın arşivsel anlamda belirlenmesi olmuştur. 


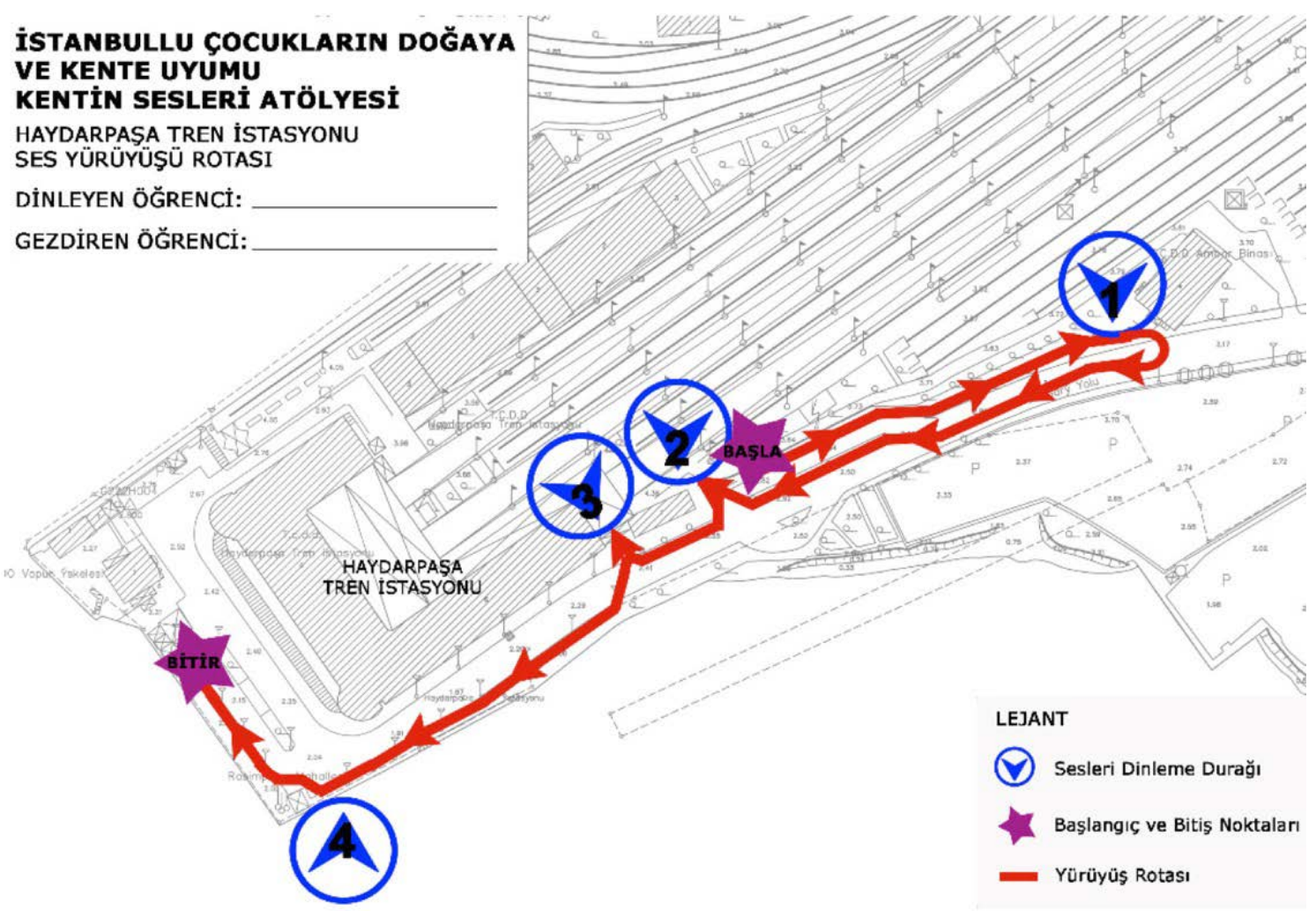

Harita 2: Kentin sesleri çalışmasındaki ses yürüyüş rotasını ve ses duraklarını içeren el haritası

(Yazar tarafından hazırlanmıştır.)

Yapılan Ses yürüyüşü ve Zihin Haritalama Çalışmasında;

-Duyulan ana sesler ve alt sesler belirlenmiştir.

-Gar ve etrafında yer alan kimlik sesler gözlemlenmiştir.

-Keyifli his, keyifsiz his ve aradaki hislerin algılandığı noktalar belirlenmiştir.

Çalışmada çocuklarla birlikte alt seslerin ve üst seslerin duyumsandığı noktalar, öne çıkan veya arkada kalan sesler, rahatsız olunan ve/ya memnun olunan ses kaynakları ve işitsel noktalar; Haydarpaşa Garı ve etrafındaki ses kaynaklarından sembol ses konumunda olanların saptanması ve korunması, yaşatılması, güçlendirilmesi gereken seslerin belirlenmesine yönelik değerlendirmeler yapılmıştır.

\section{GENEL DEĞERLENDIRME VE ÖNERILER}

Araştırma; kent mekânında işitsel peyzaj yaklaşımı çerçevesinde kullanıcı odağıyla yapılan işitsel analizler ve sesle ilgili yaratıcı girişimlerin, planlama ve tasarım alanlarıyla ilişkisini; mekân kimliği, kullanıcının mekân algısı ve mekân hafızası konuları üzerinden ortaya koymaktadır.

Kent meydanında tamamen belli noktalara özgü, benzersiz ses katmanı karışımlarının ortaya çıkarılması mümkün olmuştur. Katılımcılarla birlikte, algılanan ses kaynakları ve hislere ilişkin hazırlanan haritalar, işitsel zemindeki mekân kimliğinin izdüşümü niteliğindedir. Mekânın geçici ve kalıcı kimliği, kullanıcıların işitsel hafızalarıyla birebir ilişkilidir, dolayısıyla duyulanlar üzerinden algılanan hisler somut verilere dökülerek mekânın kolektif hafızası ortaya çıkarııırken kullanıcıların mekânla bağının niteliği belirlenmiştir.

Çalışmada ses, gürültü kontrolü yaklaşımından öte ele alınarak, üstten alta yapılanmayla rahatsız olunan, istenilmeyen seslere odaklanma ve müdahale etme 
yoluyla planlama yapmak yerine, farklı algısal boyutları da içeren (örneğin keyif veren ya da korunması istenen seslerle birlikte) bir unsur olarak ele alınmıştır. Bunu yaparken kentsel bir mekândaki işitsel peyzaj sahasında, kullanıcının aktif hale getirilmesi, karar verme mekanizmalarına dahil edilmesi de hedeflenmiştir.

Bu katılımcı modelde mekânın işitsel boyutu; Olaylılık / Keyiflilik algı modeline göre tasarım-planlama alanıyla ilgili kullanıcıların tepkilerine göre açığa çıkarılmaktadır. Böylece psikocoğrafi yaklaşımlarla kullanılan "ses yürüyüşü" yönteminin, planlama ve tasarım alanında farkındalık sağlaması hedeflenmiştir. Yöntemin bu disiplinlerde kullanıcı-mekân ilişkisini güçlendirmeye yönelik kolay uygulanabileceği ve etkin bir işitsel analiz ve sentez çalışması olarak yerini alabileceği öne sürülmektedir.

Araştırmada yer verilen saha çalışmaları arasında en kapsamlısı Kadıköy_AKUSTíK çalışmasıdır. Kadıköy Meydanı kamusal geçiş bölgesinin işitsel peyzaj açısından farklı veriler sağladığı düşünülmektedir ve bölgedeki çevresel akustiği, uzun dönemde olumlu çalışma programı çerçevesinde değerlendirmek amacıyla ses yürüyüşleri gibi algı ve gözlem çalışmalarının yapılmasına intiyaç görülmüştür. Bunun yanı sıra, çalışmada kullanılan ses yürüyüşü, ses çalıştayları ve haritalama yöntemlerinin planlama disiplininde etkin şekilde nasıl kullanılabileceğine dair bir yol haritası çıkarılması hedeflenmiştir.

Türkiye'de planlama disiplinindeki pratikler, işitsel peyzaj ve akustik algı çalışmalarını araştırma ve uygulama süreçlerine dahil edememektedir. Bunun sebebi, hem mevcut konuyla ilgili yeterli bilgi ve altyapı kapasitesinin olmayışı, hem de kentsel planlama ve tasarım yaklaşımlarındaki vizyonun sınırlı oluşudur. Burada yer alan teorik araştırma; saha çalışmaları ile birlikte kentsel tasarımcılara ve plancılara işitsel anlamda tamamlayıcı metodolojik yol ve araçları göstererek yönlendirici kılavuz önerisinde bulunmayı amaçlamaktadır.

Bundan sonraki araştırmalarda bu çalışma verileri, sahip olduğu veri altyapısı ve yönlendirici içeriği sayesinde çevrimiçi platformlara taşınabilir. Günümüzde sık kullanılan akıllı telefonlar için uygulamalar geliştirilebilir. Örneğin Kadıköy Belediyesi'nin uygulama olarak bu tür bir girişimde bulunması sağlanabilir.

Bu tür işitsel peyzaj araştırmalarının daha görünür ve "duyulur" olabilmesi adına karar verici organların, öncelikle belediyelerin, araştırma projelerinin birebir içinde olması değer arz etmektedir. Belediyeler ve ses araştırma projesi yürütücüleri kılavuz olarak bu tür çalışma verilerini rahatlıkla kullanabilirler ve katılımcı, sürdürülebilir uygulama projeleri yürütebilirler.

Ayrıca mekânsal tasarım yarışma projelerinde ses katmanının irdelenmesi yararlı sonuçlar doğuracaktır. Tasarlanacak mekâna dair önceden işitsel araştırma çalışması yapılması konusunun yarışma projelerinde kriter olarak yer alması tavsiye edilmektedir. Böylesine analitik kalitatif bir çalışmanın kentsel tasarım sürecine girebilmesi; katılımcı metodoloji, kültürel miras koruma-yaşatma, kullanıcı odaklılık gibi yaklaşımları da beraberinde getirmektedir. Demokratikleşme yolunda çalışmak isteyen belediyeler ve yerel hükümetler, faaliyetlerinde bu gibi kolay ve etkin yöntemleri kullanarak katılımcı yaklaşımlar benimseyebilirler. Pilot niteliğindeki saha çalışmalarında uygulanan metodolojinin ileride kentsel alanların tasarım süreçlerinde benimsenmesi adına, bu tür işitsel peyzaj çalışmalarının gerçekleşmesi ve tanıtılması olumlu sonuçlar doğuracaktır. 


\section{KAYNAKLAR}

Andringa, T.C. \& Lanser J., "How Pleasant Sounds Promote and Annoying Sounds Impede Health: A Cognitive Approach", International Journal of Environmental Research and Public Health,10-4, 2013, s. 1439-1461.

Anonim, Türk Çevre Mevzuatı, Türkiye Çevre Vakfı Yayını, No:134, Önder Matbaası, Ankara 1999.

Brown, A.L., "Advancing the concepts of soundscapes and soundscape planning", Australian Acoustical Society Conference, Gold Coast 2011.

Brown, A. L. \& Muhar, A, "An approach to the Acoustic Design of Outdoor Space", Journal of Environmental Planning and Management 47, 2004, s.827-842.

Çağlar, M., "I Hear You: Soundwalking In Tarlabaşı", Yüksek Lisans Tez Çalışması, Kadir Has Üniversitesi / İletişim Fakültesi, İstanbul 2013.

Davies, W., Adams M., Bruce N., Cain R., Carlyle A., Cusack P., Hume K., Jennings P., Plack C., "The Positive Soundscape Project", 19th International Conference on Acoustics, Madrid 2007.

Debord, G., Guy Debord presente Potlatch, Paris 1996.

Dubois, D. \& Reimbault M., "Urban Soundscapes: Experiences and Knowledge" Cities, 22, 2005, s. 339-350.

Kreutzfeldt, J., "Ishibashi Soundscape: Investigating the Soundscape of Urban Japan. I Kreutzfeldt, Jacob. In: Toshi Bunka Kenkyû Studies", Urban Culture, 8, 2006, s. 88-98.

Kang, J., "Urban Sound Environment", Taylor \& Francis Incorporating Spon, London 2006.

Ong, W. J., Fighting for Life: Contest, Sexuality, and Consciousness. Cornell University Press, 2012.

Schafer, R. M., The Tuning of the World, Random House Inc., NY 1977.

Schulte-Fortkamp, B. \& Fiebig, A., "Soundscape analysis in a residential area: an evaluation of noise and people's mind", Acta Acustica united with Acustica, 92, 2006.

Truax, B., "The World Soundscape Project's Handbook for Acoustic Ecology", Simon Fraser University, 1978.

Venot, F., \& Sémidor, C., "The "soundwalk" as an operational component for urban design.", The 23rd Conference on Passive and Low Energy Architecture, Geneva, Switzerland 6-8 Eylül 2006.

Westerkamp H., "Sound Heritage", 3-4 Victoria B.C., 1974, tekrar düzenleme: 2001.

Yang, W. \& Kang, J., "Acoustic Comfort Evaluation in Urban Open Public Spaces". Appl. Acoust., 66 (2), 2005, s. 211-229. 


\section{İnternet Kaynakları}

URL-1: http://en.wikipedia.org/wiki/4\%E2\%80\%B233\%E2\%80\%B3

URL-2: https://www.cieh.org/media/1256/propg-document-1_planning-noise-policyand-guidance.pdf

URL-3: http://urbansquares.com/07psychogeographyNEW.html

URL-4: http://www.urbansquares.com/

URL-5: www.salford.ac.uk

URL-6:

http://citeseerx.ist.psu.edu/viewdoc/download?doi=10.1.1.577.6321\&rep=rep1\&type=p df

URL-7: http://plearch.org

URL-8: http://is.cuni.cz

URL9:

http://www.natureconservancy.ca/assets/images/graphics/nat/naturerx/NatureRxsoundwalk.pdf 